\title{
Extending Promising Pest Management Practices among the Vegetable Growers of Western Region of Bulandshahr (Uttar Pradesh), India
}

\author{
R.V. Singh, Meenakshi Malik*, A. K. Kanojia and Neelam Mehta
}

ICAR-National Research Centre for Integrated Pest Management-110012, India

*Corresponding author

\section{A B S T R A C T}

\section{Key words \\ IPM, Vegetable crops, Constraints, Adoption, \\ Validation, \\ Collaborative \\ Approach, Farmer's School \\ Article Info \\ Accepted: \\ 26 June 2018 \\ Available Online: \\ 10 July 2018}

The Bulandshahr district of Uttar Pradesh has been selected for the extension of promising IPM technologies in selected vegetables as the state is the second largest producer of vegetables in the country after West Bengal. The total area covered under vegetables is 0.84 million ha which account for a total production of 15.8 million tonnes. The aim of the project is to promote awareness and knowledge among the farmers and to fill the technological gaps. Extension of IPM technologies through innovative extension tools in participatory and collaborative approach is most effective.

\section{Introduction}

Integrated Pest Management (IPM) is the information regarding the pest abiotic and biotic factors, agro-ecosystem and management tactics that are required for execution of pest management programmes. It can also be defined as an agro-ecosystem management technology for sustainable crop production. Acreage devoted to individual vegetable crops is small but economic returns per acre are substantially higher than those from agronomic crops. A higher portion of the cost is represented in the pest management in producing the major agronomic crops (i.e. cotton, corn, soyabean) and producers are highly responsive to approach that reduces costs. Because vegetable growers primarily face risks in product quality and markets, the adoption of IPM practices has been more challenging because of the disparity in production costs and economic risks between the two kinds of crops. IPM technologies first were developed to address the prospect of economic ruin in agronomic crops and later were adapted to vegetables. Vegetable production plays a pivotal role in agriculture by providing food, nutritional and economic security to the people of with higher returns per unit area to the producers. India holds the 
second position by contributing 15.70 and 14.50 per cent to global vegetable area and production.

Economic realities in vegetable production changes the producer behavior and decision making far more challenging than in agronomic crops because of several factors. Short-term economic gains in chemical pest control is offset by the longer term biological reality of pesticide resistance in pests of all crops. Over-reliance on insecticides greatly increases long-term risks of resistant pests emerging for which no short-term remedy is economically available. Development and implementation of IPM in vegetables is further exacerbated by ecological realities of crop host and pest diversity.

\section{Location selection}

Uttar Pradesh holds a vast potential for the development of horticulture and it is the largest state of the country in terms of population and second largest in terms of area in the country. The diverse and suitable agroclimatic and agro-ecological situations have enormous potential for horticultural crop production in the state. The 24.2 million ha is the reported area of the state out of which 16.68 million ha is the cultivated area and the gross cropped area is 25.5 million ha. The cropping intensity in the state is 153 percent. The small and marginal farmers dominate the farming community and the average size of holding is only 0.83 ha per farmer whereas the average size is 0.40 hectare only of holding of marginal farmers. The state accounts for 11 per cent India's net sown area and contributes more than 41.1 million tonnes of foodgrain which is about 20 percent of the total foodgrain production of the country. The state produces 38 percent of India's Wheat, 20 percent of Paddy, 21 percent of Sugarcane, 34 percent of Groundnut, 17.5 percent of Rapeseed, 8 percent of Fruits and 16 percent of Vegetables. Uttar Pradesh holds the position of second largest producer of vegetables in the country after West Bengal. It has an area of 0.84 million ha under vegetable which account for 15.8 million tonnes production (Singh et al., 2016).

Agro-climatic Zone- Central Western Region (Zone 3 ) is traditional vegetable growing area of the state. This ecological zone consisting of districts namely Bulandshahr, Saharanpur, Ghaziabad, Gautam Buddh Nagar, Muzaffarnagar, Meerut and Baghpat. The soil of this region are clayey- alluvial, sandy alluvial and sandy types. The average annual rainfall of this zone is $600-965 \mathrm{~mm}$. Among all the districts of the mentioned geographical area of the ACZ 3, Bulandshahr is a traditional and important vegetable growing area in the western region of Uttar Pradesh in the mentioned zone. Vegetable development, in this area has taken place due to better marketing facilities and potential of marketing for National Capital Territory Region Delhi. Significant increase in area under vegetables has been recorded on small and marginal farms since it provides an international market for vegetables. Demand is always high due to higher population density in urban area and high income of the people residing in these areas. The most of the vegetable cultivation is concentrating adjoining the urban areas. The major vegetables grown in the district arepeas, chilies, okra, tomato, brinjal, cauliflower, cabbage, spinach, melon, radish, carrot, turnip and cucurbits. These crops have proved to be the boon to the small and marginal farmers of the district. Vegetable cultivation has a great scope and potential for improving the socio-economic conditions of small and marginal farmer providing higher yields and high economic returns in short span of time as compared to food grains (Singh et al., 2010).

In this area, the networking of research, extension, marketing and processing infrastructure are strengthening the vegetable 
production and export orient food park. The production and quality of the vegetable crops are directly influenced by the pests resulting in 25-30 per cent yield losses. Keeping in view of vast potential, the state has major role to play in economic growth of the country. There is tremendous scope for further development in every sub-sector of the agriculture sector including crops, horticulture and animal husbandry.

\section{Role of IPM}

Pest control practices in the vegetable crops have been heavily dominated by the routine use of broad-spectrum insecticides to control pests. To mitigate the losses farmers depend on chemical pesticides and accessing pest management information and inputs from the pesticide dealers due to weak state extension support system. Concerns have emerged about the adverse consequences of over use of pesticides. These consequences include short and long-term health hazards, contamination and environmental degradation. Indian farmers have been found to follow unsafe pesticide handling practices including spurious brands, expired chemicals, substandard equipment, overdosing, non-adherence to label claims, not wearing protective clothing besides poor or unsafe storage and disposal (Sam et al., 2008; Baral et al., 2006) and hence serious health impacts are common, requiring medical attention (Mancini et al., 2008). Adoption of IPM methods can be driven through necessity, economics and market requirements, but sufficient supporting information and advice is a key to IPM adoption. Since the 1980s, Integrated Pest Management (IPM), the combination of various management methods (Mason, 2003), gained importance in India through favor in policy and extensive promotion of IPM programmes in vegetables (Singh et al., 2003). Many research institutions are facing difficulties to reach farmers and translating the
IPM innovation in adoption at field level. NCIPM has developed and promoted IPM technologies to manage pests in selected vegetable crops by implementation of IPM projects in vegetable crops through participatory approach since 2000 .

\section{Lack of adoption in IPM}

Integrated pest management (IPM) has been the dominant crop protection paradigm that has been promoted globally but inspite of several socio-economic and environmental advantages of these technologies; the adoption of IPM at the farmer level is not very encouraging. Adoption is limited, however, due to technical, institutional, social, cultural, economic, educational and informational and policy constraints. Future expansion of IPM in developing countries will depend on success in reducing each of these constraints (Norton et al., 2005). Studies on the constraints in adoption of IPM technologies in selected vegetable crops were conducted by authors to identify the constraints in the adoption of IPM in vegetable crops. It has been concluded that the adoption of promising IPM technologies were not satisfactory due to socio-economic, technological and institutional constraints. Factors such as weak state extension support, pest management information and input delivery, marketing strategies and aggressive propaganda and malpractices of pesticide dealers/companies were prevalent in vegetable growing areas.

\section{Promotion of IPM technologies}

Participatory approaches such as Farmer Field School (FFS) and Participatory Action Learning (PAL) have proved to be very successful in promotion of Integrated Pest Management in vegetable crops and used to engage IPM stakeholders as to complementary groups that together could support the range of extension needs. One of the most effective 
method of training- extension on integrated pest management, farm is on the way to school. This method of learning about the ecology and management of cultivated land area cultivated by very practical ways for farmers to provide. The purpose of this research introduces teaching methods- a school extension in the field as an effective method of training in integrated management of pests. The results showed that the extension of school education in the field, is a very effective way to achieve sustainable agriculture in the context of integrated pest management training. Extension workers or trained farmers facilitate the learning process, encouraging farmers to discover key agroecological concepts and develop IPM skills through self-discovery activities practiced in the field (Ooi, 1996). In participatory extension approach, farmer-facilitators have proved to be motivated and sometimes more effective than their professional counterparts because farmers appreciate learning from peer with similar experience who speak their local language (van de Fliert et al., 1995). The proactive role of state extension agencies such as KVKs and State Department Agriculture for information delivery and input supply certainly will motivate the farmers for adoption of IPM. Therefore, accelerating the adoption of IPM in vegetable crops by involving the public and private extension with farmer for extending the promising vegetable IPM in participatory mode is needed on priority. The consequences of the approach to the farmer, farm schools, Gosthi, Group discussions, Focus meetings are as follows:

1 - Increasing the capacity of farmers for research, innovation and informed decisions

\section{2 - Develop the capacity of farmers}

3 - To encourage farmers to facilitate their learning and research processes
4 - Increased sense of responsibility towards the demands and needs of the audience through a national system in the research, using a variety of sources, most information was derived.

The adoption of IPM practices can be maximized by educating and visualizing the importance of IPM practices among the farming community (Ram et al.2012). National Research Centre for Integrated Pest Management has an important role in emphasizing the identification of the barriers and constraints directly related to the low adoption of IPM technologies in vegetable crops. The project would help to enhance knowledge, awareness and adoption of promising IPM practices through innovative extension tools and the capacity building and scaling up programmes for IPM stakeholders for better technology transfer and adoption of IPM, in so doing, effectively help sustain vegetable production.

In conclusion, the project is based on an Extension programme for conducting studies to identify the existing IPM technological practices, information, knowledge and technological gaps, training and information needs of farmers and extension personnel towards IPM in selected vegetable crops of the project location. This approach would ameliorate the constraints in IPM adoption at farmer level through active collaboration with extension agencies for facilitation of IPM information, knowledge, training and extension literature and extension activities. Amelioration of constraints from the project may help to decrease the chemical consumption and thus directly improve quality of vegetable produce, socio-economic condition of farmers and also will develop social capital and healthy environment. The project output may also support IPM extension mechanism for promotion of IPM.

References 
Bakshi et al., Integrated Pest Management: Means for sustainable Agricultural development in developing countries. Pakistan Journal of Social science. Vol. 3(4), pp. 603-613, 2005.

Bakshi et al., IPM is a knowledge intensive system; farmer education approaches have been developed. CGIAR's System wide IPM (SP-IPM) programme uses Pilot sited to build effective Farmer-Scientist-Extension (FSE) partnership (CGIAR 2002) for successful promotion of IPM as collaborated efforts. Increased collaboration among scientist, extension agencies, private sector and farmers is necessary to address farmers concerns and ensure adoption of research results. 2005.

Baral et al., Indian farmer have been found to follow unsafe pesticide handling practices such as not wearing protective clothing, pesticide misuse and serious health impacts are common, requiring medical attention. 2006.

Baral et al., Socio-economic Parameters of Pesticide Use and Assessment of Impact of an IPM Strategy for the Control of Eggplant Fruit and Shoot Borer in West Bengal, IndiaTechnical Bulletin No. 37, AVRDCThe World Vegetable Centre, Shanhua, Vol. 16, pp. 2-3, 12-13. 2006.

Burfield et al., During Australian IPM vegetable extension project he was observed and found the value of Participatory Action Learning (PAL) as a very effective communication process that could be used to develop, test and apply tools and messages to support IPM adoption. 2005.

Capinera et al., Handbook of vegetable pests. Academic Press. Orlando. FL. 2001.
Dent et al., Institutional Constraints to IPM. H. Waibel and J. C. Zadoks (Ed). Study presented at the 13th International Plant Protection Congress, The Hague, 2-7 July, 1995. Hannover. 1996.

Edelson et al., Economics of controlling thrips on onions in south Texas. J. Econ. Entomology. Vol. 82, pp. 561564. 1989.

Fliert et al., Searching for strategies to replicate a successful extension approach: training of IPM trainers in Indonesia. European Journal of Agricultural Education and Extension Vol. 1(4), pp. 41-63. 1995.

Higley et al., 1992. A novel approach to environmental risk assessment of pesticides as a basis for incorporating environmental costs into economic injury levels. Am. Entomol. Vol. 38, pp. 34-37. 1992.

Higley et al., A novel approach to environmental risk assessment of pesticides as a basis for incorporating environmental costs into economic injury levels. Am. Entomol. Vol. 38, pp. 34-37. 1992.

Metcalf et al., Insecticides in pest management- In R. L. Metcalf and W. H. Luckmann (Eds.). Introduction to insect pest management. Wiley \& Sons, pp. 280-281. New York. 1994.

Norton et al., The Need for Cost-Effective Design and Diffusion of IPM edited in Globalizing Integrated Pest Management- A Participatory Research Process, Blackwell Publishing, USA. 2005.

Ooi et al., Experiences in educating rice farmers to understand biological control. Entomophaga Vol. 41, pp. 375-385. 1996.

Shashekala et al., Constraints of small farmers for their agricultural development. International Journal of 
Science and Nature. 2012.

Shashekala et al., Wider adoption of technology requires the technical knowhow should be accompanied by credit, marketing, extension service, technical back-stopping and other important institutional supports. 2012.

Singh et al., Adoption Behavior of Commercial Vegetable Growers in District Ghaziabad (UP). 2003.

Singh et al., Economic Analysis of Vegetable Production in Meerut District of Uttar Pradesh, International Journal of Tropical Agriculture Vol. 34(3), 2016.

Singh et al., IPM gained importance in India through favour in policy and extensive promotion of IPM programmes in vegetables. 2003.
Smith et al., Intercropping and pest management; a review of major concepts. Am. Entomol. Vol. 46, pp. 154-161. 2000.

Thomas et al., The adoption of integrated pest management practices among Texas cotton growers Rural Soc. Vol. 55. Pp. 395-410. 1990.

Uttar Pradesh Annual Action Plans of 201011 to 2012-13 of State Horticulture Mission, U.P. for the Development of Horticulture in the State.

Vanderman et al., 1994. Adoption of integrated pest management in U.S. agriculture. U.S. Dep. Agric. Econ. Res. Serv. Agric. Info. Bull. Vol. 707. 1994.

\section{How to cite this article:}

Singh, R.V., Meenakshi Malik, Kanojia, A.K., Neelam Mehta. 2018. Extending Promising Pest Management Practices among the Vegetable Growers of Western Region of Bulandshahr (Uttar Pradesh), India Int.J.Curr.Microbiol.App.Sci. 7(07): 3467-3472. doi: https://doi.org/10.20546/ijcmas.2018.707.402 